\title{
Journey to natural history museum in perspective of children
}

\author{
Ayşegül Evren Yapıcıoğlư1, Sevilay Atmaca², Aydın Akbulut ${ }^{3}$, Gaye Defne Ceyhan ${ }^{4}$, Yusuf \\ Durmuş 5 , Galip Akaydın ${ }^{6}$ and Ali Demirsoy ${ }^{7}$ \\ ${ }_{1}^{1}$ Science Education Department, Muğla Sttkı Koçman University, Muğla, TURKEY \\ 2 Ankara, TURKEY \\ 3,6 Biology Education Department, Hacettepe University, Ankara, TURKEY \\ ${ }^{4}$ Department of Science Teaching, Syracuse University, Newyork, USA \\ 5, 7 Science Faculty of Biology Department, Hacettepe University, Ankara, TURKEY \\ For correspondence: aevren@mu.edu.tr
}

\begin{abstract}
Interest against the science, to increase permanence of learned theoretical knowledge can be provided via visual, auditory and tactile science and technology lessons in schools. Museums are seen as the key learning areas that aim to reinforce the learning and to show concrete face of science. Easy and comfortable transportation to museums in major cities is a big advantage comparing to the students who live in provincial cities and does not have same chance. In order to give a chance to those students, the elementary schools students in the five district of Eastern Anatolia Region experienced their first journey to a natural history museum in TURKEY. This educational journey to Prof. Dr. Ali Demirsoy Natural History Museum was supported by TUBITAK. The study was carried out to help student observe and experience the natural museum from children's perspectives. Children perspectives' about Prof. Dr. Ali Demirsoy Natural History Museum comprises of three categories, which are expectations and estimates, experiences (Subcategories are observation and emotional experiences) and reflections of attitude.
\end{abstract}

Keywords: Science Education, Informal Learning Environment and Natural History Museum

\section{Introduction}

People often regard schools as formal learning environments and as the only place where learning activity takes place. The establishment of this traditional view in a cultural context creates a feeling that the learning process is over when the children, the little units of the community come home from school. Schools become the institutions of a mandatory process for them. However, learning takes place with various sources, various places and various reasons. (Shaby, Ben-Zvi Assaraf ve Tishler, 2016).

Informal learning takes place at every moment and everywhere while individuals perform a limited part of their lives in formal education institutions (Türkoğlu, 2009). Millions of people in the world visit informal learning environments such as zoos, aquariums and science centers for fun or educational purposes (Anderson and Lucas, 1997). The mentioned informal environments, as institutions providing the link between formal education and informal education, increase the quality of teaching and provide active participation of the students (Stocklmayer, Rennie and Gilbert, 2010). The importance of replacement of these institutions in curriculum, which are described as informal learning environments in education for many years, has been emphasized (Osborne and Dillon, 2007). In the report published by the National Research Institute, informal learning environments are evaluated in three categories. Museums, zoos, science centers and libraries are in the organized informal environments category (NRC, 2009). This study focuses on museums, one of the organized 
informal environments, which constitute the first concrete steps of the individuals' historical journeys in the historical process and museum education.

According to International Council of Museums, museums are nonprofit institutions serving for the development of the society, serving for entertainment, research and education, which shed light on the future as well as on the past, where the heritage of mankind and objects of the nature are preserved and exhibited (ICOM: International Council of Museum). However, when historical process examined, it can be said that a change has been experienced in the general purposes of museums. Since the 20th century, museums have become educational environments that play a role in the education and teaching all ages of people, beyond being a place to have a good time (Atagök, 1999; Güler, 2011). Particularly for children at primary education level, traveling at an unprecedented time contributes to physical, cognitive and emotional development of them. In the museum's historical vision, these developments have led to the emergence of different types of museums. The International Council of Museums (ICOM) has stated the types of museums as follows (Çetin, 2002):

- Art Museums

- Archaeological and Historical Museums

- Ethnography Museums

- Natural History Museums

- Science and Technology Museums

- Regional Museums

- Special Purpose Museums

Science Museums and Museums of Natural History have their own characteristics that make them different from archaeology and ethnography museums. Demirsoy (1996) has defined natural history museums as institutions that preserve plant and animal samples from all over the world, fossils, rocks and geological formations; that put them in scientists' and amateur naturalists' service to be studied on; that give education on protecting the nature and therefore the environment by organizing publicoriented exhibitions and conferences. Visitors at these museums not only look at the objects but also touch them. They activate the objects as they wish by observing their operating mechanisms (Çetin, 2002). Today, almost every city in Europe has a museum of natural history (Dilli, 2014). In Turkey, operating for this purpose, MTA Museum of Natural History is in Ankara, Ege University Museum of Natural History is in Izmir and Istanbul Technical University Corridor Museum is in Istanbul. Considering the locations of the museums, it appears that they are all located in the big city centers. This situation causes the children who continue their education in the inner regions of Turkey (Eastern and Southeastern regions) under the conditions they have, not to be able to benefit from the learning and teaching activities that take place in museums.

In order to provide equal opportunity in education and to solve this problem, the first application has been realized with "Ali Demirsoy Natural History Museum (ADNHM)" established in Kemaliye county of Erzincan province. In 2006, in the scope of the project "Creating the Natural History Museum of Kemaliye", which was realized with the support of ADNHM, TUBITAK and Erzincan University, 38 scientists came together and complied various examples from many regions of Turkey, especially Kemaliye and its surroundings. This museum, which is the first natural history museum in Eastern Anatolia, exhibits nearly five thousand species and is used as a training center (İslamoğlu, 2012). ADNHM has four main objectives.

- To promote our natural assets for the region, the educational institutions in the surroundings and touristic trips; to protect them; and to provide training,

- To establish a sample for the planned "National Natural History Museum",

- To contribute to the awareness of the society about the facts, concepts and generalities related to the history of nature and protection of nature,

- To encourage the opening of similar local museums in all the cities in Turkey. 
Within the framework of these general objectives, for the primary school students in the surroundings, a museum training program called "Scientific Trip in Natural History Museum" was designed and implemented by the museum founders within the scope of the project supported by TÜBITAK.

\section{Background of the Study}

Today, museum has undertaken a very important task of education, in addition to the pre-existing responsibilities such as collection, documentation, storage and exhibition (Dilli, 2014). Now, it has made a transition to the living contemporary museology understanding where new teaching approaches are used and which is fictionalized as a cultural unit from the stable space understanding of classical museum which stay isolated from society (Şar and Sağkol, 2013). Among the other objectives, museum and thereby museum education has the responsibility of illuminating the society through lifelong training, helping science become widespread, contributing to the development of democracy first within itself and then within the society (Hooper-Greenhill, 1999). From the point of view that everyone can be trained at any age, museum has become one of the most suitable environments in which life-long education can be offered (Güleç and Alkış, 2003). Through museum education, people's thoughts and feelings are stimulated and they are motivated to learn (Şahan, 2005).

When studies on museums and museums are examined in Turkey, it is seen that most of them are generally planned as theoretical works (e.g. Çetin, 2002; Dilli, 2014; Kuruoğlu-Maccario, 2002; Mercin, 2006; Adıgüzel, 2006; Akmehmet and Ödekan, 2006). In studies involving empirical experiences for museum education, it was determined that the research areas applied are mostly visual arts education and art education (Canl1, 2016; Güler, 2011; Kaya-Koçak, 2010; Tosun, 2009) and history and social studies education (Egüz and Kesten, 2012; Güler, 2011; Karadeniz and Okvuran, 2014; Selanik-Ay and Kurtdede-Fidan, 2014) In museum education research, children and/or adults (Falk ve Dierking, 1997; Gilbert and Priest, 1997; To, Tennenbaum and Wormald 2016;), students (Anderson and Lucas, 1997; Cox-Peterson, Marsh, Ksiel and Melber, 2003; Güler, 2011; Martin, Durksen, Williamson, Kiss and Ginns, 2016, Mortenson and Smart, 2007), teachers (Stetson and Stroud, 2014; Tal, Bamberger and Morag, 2005), visitors and museum staffs (Shaby, Ben-Zvi Assaraf ve Tishler, 2016; Tran, 2006) are the samples searched as study groups. Despite being very new in terms of practices and studies in our country, the use of museums as a learning environment in science education has been searched on the international platform for many years. According to Allen (2004), exhibition spaces in museums are considered educational alternatives that encourage, entertain, appeal to a multitude of senses, provide a lot of evidence, and provide relevant practices for science lessons in schools. Teachers believe that museum visits, in particular, encourage the development of scientific and social skills as well as they increase the interest and motivation of students (Michie, 1998). Many museum programs have been developed as supporter, complement, and fortifier of science programs (Rennie and McClafferty, 1995). Indeed, in many countries, museums being increasingly involved in teaching programs in science and technology education are regarded as the reason why museums are highly mobile and used (Gilbert and Priest, 1997). Shaby, Ben-Zvi Assaraf and Tishler (2016) emphasize in the research they did with the educational specialists working in science museums in Israel, Europe and America that science centers have an important role in the visitors' point of view towards science and make science accessible for public. According to Falk and Dierking (1997) school trips to museums and other informal environments support long-term remembrance of the science content. It is revealed that the children and adults participating in this study remembered $80 \%$ of three or more special events related to a school trip. Finson and Enochs (1987) stated that museum visits affected student attitudes toward science-technology-society. 
Researches on museum education are mostly focused on eye-catching exhibitions, museum personnel, and the way of perceiving the objectives of the museum, and the students' cognitive learning outcomes and attitudes. This research focuses on the primary school students' perceptions about ADNHM and the experiences they had in the museum.

Purpose of Study

The purpose of the study is to describe a natural history museum in the eyes of the primary school students attending the TUBITAK supported education in the natural history museum. To achieve this goal, the research problem is formulated as "How do primary school students describe their experiences with ADNHM?" The sub-problems identified in the framework of the research problem are as follows;

- What are the expectations and estimates of the primary school students' experience with ADNHM?

- What are the experiences the primary school students have had in ADNHM?

\section{Method}

The study was planned with a focus on the "natural history museum" event in the eyes of primary school students. For this purpose, the perceptions of the students about the museum and the experiences they have had in ADNHM have been considered as the main points of action. The phenomenological research design, one of the qualitative research methods, has been used because the center point of the study is people's perceptions and experiences on a subject. According to Lichtman (2010), the purpose of phenomenological research is to define and understand the quality of experiences of individuals who experience the part of a phenomenon. The personal experience of a focused phenomenon is reduced to a universal definition (Creswell, 2007). In addition, descriptive phenomenological research (Reiners, 2012) has been used in the study to protect the primary school students' perceptions and experiences on the natural history museum and to reach some generalizable universal qualities (Saban and Ersoy, 2016). Therefore, the main purpose of the research is to describe the perception and experiences of primary school students towards ADNHM, not to comment on it.

\section{Participants and Environment}

ADNHM was established in order to serve the whole community, especially the students in the educational institutions in Kemaliye and its surroundings, in Kemaliye county of Erzincan province in the Eastern Anatolia of Turkey. For this reason, the study was conducted with a total of 633 students at the 6th, 7th and 8th grades of primary education in five counties in the Eastern Anatolia Region. The selected counties are Çemişgezek-Tunceli, Arapgir-Malatya, Ilic-Erzincan and AğınElazı $\breve{g}$, which are closest to Kemaliye county in Erzincan province where the museum is located. Permission for the students has been obtained from the relevant district governors for their participation in educational activities. The principle of equal opportunity was followed in the selection of students by the help of the information received from the provincial and district National Education Directorates. The age range of the students is between 12 and 16. The schools where the participant groups come from generally have inadequate equipment in terms of educational materials and learning environment. Students reported that their schools didn't have laboratory environments, one of the basic elements of science and technology education.

According to the decision of the Erzincan University Senate, the study was carried out in the place called ADNHM within the body of Erzincan University Kemaliye Haci Ali Akın Tourism Hotel Management School. The applicable area of ADNHM consists of a total of one thousand square meters consisting of two large saloons and four rooms. The outline of the ADNHM consists of the following sections; Room A consists of two parts where the geological structures (volcanic rocks, 
sedimentary rocks, metamorphic rocks, precious mines and stones, etc.) and fossils are. Room B is mainly composed of three sections where can be seen various life forms, especially plants (algae, lichens, algae, seedless plants, mushrooms, flowering plants), invertebrates (sponges, jellyfishes, flatworms, insect specimens etc.), vertebrates (fish, amphibians, reptiles, birds and mammals). Besides, there are conference rooms for 400 and 100 people, which are expected to be used for museum education purposes. Below are the pictures related to the museum (Figure 1).

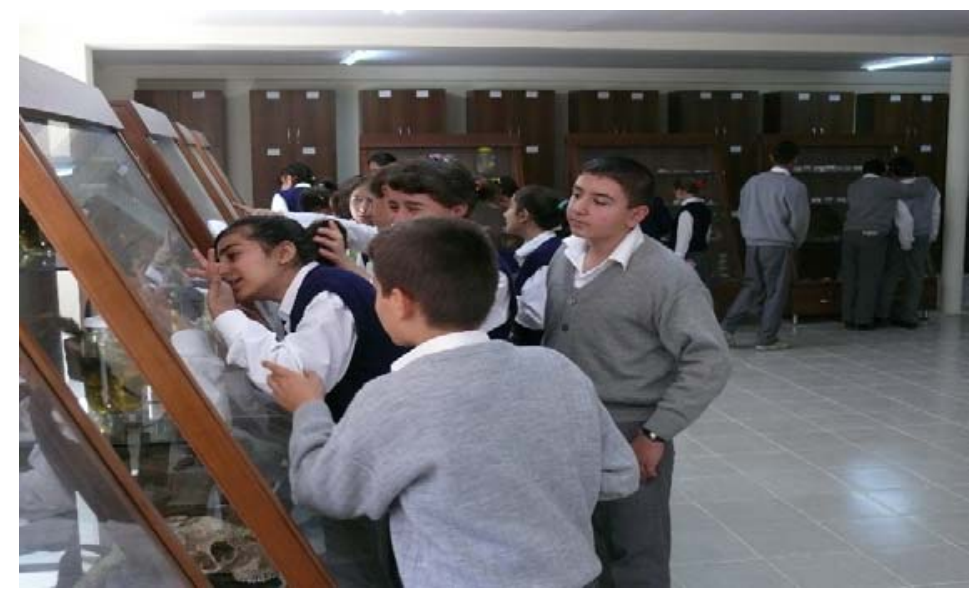

Figure 1. Ali Demirsoy Natural History Museum, Room B.

Process

In every group there were 20 students who come to the museum by private service buses from their schools were taken to the meeting hall first. Here, in order to determine their expectations about the museum, the students were given an open-ended question "What do you hope to live in the ADNHM?" and asked to give a written answer. After taking the students' opinions, preliminary information has been given about the processes that took place from the formation of the universe up today and about the prominent the creatures of our country and the region. During this briefing, large group discussions, question-answer techniques and visual materials were frequently used (Figure 2).

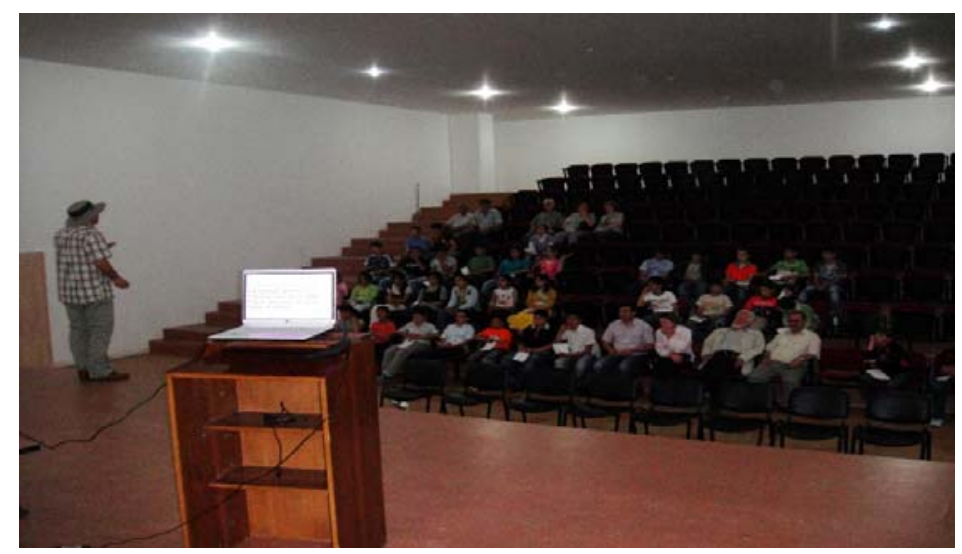

Figure 2. Preliminary Information Phase

In the second phase of the program, the students performed the observations and the experiments themselves in accordance with the steps of the scientific method process, in the guidance of the experts (Figure 3). The workshops carried out at this stage and the expected scientific process skills are as follows;

- What is in a Drop of Water? (Making observations, making predictions, making inferences)

- Do not underrate Stone! (Observation, classification, comparison)

- Micro Cosmos (Observation, classification, comparison)

- Circulatory system in the frog (observation and experimentation) 
- The World of Algae (observation and experimentation)

- The world of flowering plants (observation, classification, experimentation)

- The world of mushrooms (observation, experimentation, classification, making inferences, measuring)

- The World of Insects (observation, prediction, inference)

- Reproduction in vascular plants (observation, experiment, measurement and classification)

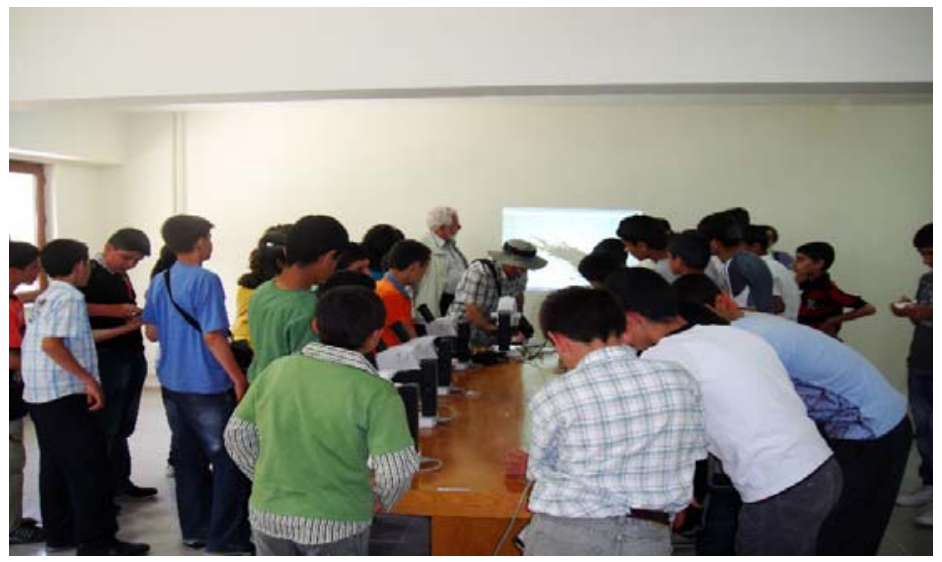

Figure 3. Practice phase

At the end of the training, students were asked the open-ended question: "What are the experiences you have had in the ADNHM?" In addition, they were again asked to give written answers. After receiving the answers from the students, they were provided access to their schools by private service buses.

\section{Data Collection Tool and Analyze}

Two written questions were given to the participant group in order to bring forth the ADNHMoriented experiences they had hoped for and the experiences they had. Before the museum visits; asked the question "What do you hope to live in the ADNHM?" After the museum education had been completed, asked the question "What are the experiences you have had about the ADNHM?" In this regard, the collected data have document quality. The first reason for using the document as a method of data collection is to provide participants with the opportunity to express freely and comfortably their perceptions and experiences. The second reason is the opinion that the elementary school students who make up the participant group of the study are young in terms of age level and that they can express their feelings and experiences more easily in written form. Researchers and educators did not use the interview method in the study because they meet with the participant group for the first time.

The inductive descriptive analysis method, one of the qualitative data analysis methods, was used to analyze the written documents obtained. In order to gain a holistic viewpoint without starting the analysis of the data in the research, each individual's document was read several times in order to be able to recognize them better and to be able to notice the codes.

By means of phenomenological data analysis technique, then codes were given by analyzing the documents, sentence by sentence, and word by word. The categories were determined by using the codes obtained from the analysis of the documents. Moreover, based on the codes the categories were specified. The relationships between the categories and the codes obtained in the research have been analyzed with a systematic approach. In phenomenological data analysis, it was tried to be explained how individuals experienced the phenomenon by taking important situations, statements, or quotations from the data collected from the individuals (Creswell, 2007). A descriptive approach was followed by direct quotations of participants' opinions and attempts were made to reach generalizations from the relationships between the descriptions. 


\section{Findings And Results}

As a result of the analysis of the data obtained, two basic categories of "expectations and estimates" and "experiences" were determined in the direction of research problems. There are three subcategories of the basic categories of experiences. These are "emotions", "attitudes" and "observation results". Below are the experiences that the students hoped for and expected to live related to the categories and subcategories, and the experiences they lived in are presented in two subsections.

Expectations and Estimates of the Students Before Seeing the Museum

While students are explaining their expectations and estimates of the experiences they will live in natural history museum, they explained with expressions such as learning, seeing new things (Code 9 ), and collecting information (Code 5) concerning with the living and nonliving components of nature (Code 1), forests (Code 6), the history of nature (code 2), old objects (Code 3), the former live (Code 4), the missing creatures of nature (Code 7) and current living (Code 8 )(Table 1). There are expressions such as old objects, missing living things, living things and history of nature, which are emphasized in different descriptions. With these expressions, it can be said that the students combine with the archaeological and historical or ethnographic museum on the history of nature. There are also codes containing action statements such as seeing new things, collecting information, and learning. These codes demonstrate that they will use more eye senses and expect to obtain one-way information at ADNHM. There is no expectation among students to interact with objects and experts or to gain experience with the application. It is also seen that they predicted the museum as a stable educational environment. A list of quotations from sample student explanations and codes on experiences that primary school students hope to live in ADNHM were indicated below.

Table 1. Expectations and Estimates of Students about Experiences to Live in ADNHM

\begin{tabular}{ll}
\hline Expressions of Students & Code No and Description \\
\hline $\begin{array}{l}\text { S4: ... I guess I learn what is happening in nature, how the } \\
\text { Earth is formed. }\end{array}$ & $\begin{array}{l}\text { Code 1: Living and non-living } \\
\text { components of nature } \\
\text { Code 2: History of nature }\end{array}$ \\
\hline S29: ... I hope to see old objects. I hope to see what animals & $\begin{array}{l}\text { Code 3: Old objects } \\
\text { Code 4: Old living things }\end{array}$ \\
were in the past. & Code 5: Gathering information \\
\hline S 57: Information about nature (we will collect). & Code 6: Forest \\
\hline S: 367: I hoped I would see the forests here. & Code 7: Missing living things \\
\hline S 120: We came here to learn the missing living things in & \\
nature. & Code 4: Old living things \\
S 208: I came to see and recognize the animals that lived in & Code 8: Current living things \\
the past and now, and to gather information about the & Code 1: Living and non-living \\
living things and the non-living things. & components of nature \\
& Code 5: Gathering information \\
\hline S 314: I came to learn and see new things" & Code 9: Seeing and learning new \\
& things \\
\hline
\end{tabular}

Experiences about Natural History Museum

While the initial expectations and predictions of the students at the natural history museum included more limited expressions, they began to use more detailed and varied expressions related to the living and non-living forms that they encountered in museum after the training in the museum. When counting the names of the living and non-living forms, which they have encountered and seen (observational results), they used cues that indicate that this environment is beyond their expectations (Table 2). 
Table 2. Students' Observations Experiences in ADNHM

\begin{tabular}{ll}
\hline Expressions of Students & Code No and Description \\
\hline S 46: I saw animal and plant species. Then examined & Code 10: Animal and plant species \\
under the microscope. I saw living things beyond my & \\
expectations. & \\
\hline S 67: ... I gathered information about the living things. I & Code 11: The living things that they \\
saw the living things that I have not seen before. & have never seen before \\
\hline S $153 . .$. I learned vertebrate, invertebrate animals, & Code 12: Vertebrate and invertebrate \\
learned stone varieties, learned how dinosaurs died, acres & animals \\
were toxic or non-toxic & Code 13: Stone types \\
& Code 14: Comparison and Identification \\
\hline $\begin{array}{l}\text { S187: ... in this museum I learned vertebrate and } \\
\text { invertebrate animals. Reptiles, worms, bugs, etc. }\end{array}$ & Code 12: Vertebrate and invertebrate \\
& animals \\
\hline $\begin{array}{l}\text { S205: In this museum, we have examined animals, old } \\
\text { fossils, and living organisms in the microscope. Completed }\end{array}$ & Code 18: Fossils \\
animals and animals in conserved jars, the fossils were & \\
very interesting. & Completed creatures \\
\hline
\end{tabular}

When we look at the expressions used by the students, it is seen that after the training program in the museum, they have gained experience in acquiring scientific process skills such as recognizing living and non-living forms (e.g Code 16: Reptiles, Code 18: Insects) and classification (e.g Code 12 vertebrate and invertebrate animals). After visiting the museum students were able to learn and use the domain-specific concepts correctly. They also stated that this journey was above the expectations of the students.

The research, in ADNHM trip, forms emotional expressions in the positive aspect of the participants' experiences. When the trip ended, they used the following sentences and codes, which also express the feelings and thoughts related to the trip in the museum (Table 3).

Table 3. Emotional Experiences of Students in ADNHM.

\begin{tabular}{|c|c|}
\hline Expressions of Students & Code No and Description \\
\hline $\begin{array}{l}\text { S 98: ... I saw things that I have never seen before, in the } \\
\text { museum. I was very happy. }\end{array}$ & Code 20:Happy \\
\hline S 44: ... Our days are a lot of fun. We are very happy. & Code 20:Happy, Code 21: Funny \\
\hline $\begin{array}{l}\text { S 87: ... The museum is so beautiful I always want to visit } \\
\text { that museum. }\end{array}$ & Code 22: Good \\
\hline $\begin{array}{l}\text { "S 123: ... I am very surprised that I am very happy to } \\
\text { come here and I would love to see again. }\end{array}$ & Code 20: Happy, Code 23: Willingness \\
\hline $\begin{array}{l}\text { S } 242 \text {... I would like to live here, I would like to possess } \\
\text { this museum }\end{array}$ & Code 23: Willingness \\
\hline $\begin{array}{l}\text { S 345: ... I liked this trip very much, I wish I were in the } \\
\text { 5th grade, I could come for another trip (next year). }\end{array}$ & $\begin{array}{llll}\text { Code 24: } & \text { Enjoying, Code 23: } \\
\text { Willingness } & & & \\
\end{array}$ \\
\hline $\begin{array}{l}\text { S 378: ... I would like to thank the people who founded this } \\
\text { museum for their hard work. I want this trip to be } \\
\text { repeated. }\end{array}$ & $\begin{array}{l}\text { Code 25: Thankfulness, Code 23: } \\
\text { Willingness }\end{array}$ \\
\hline
\end{tabular}

Primary school students have positive emotional experiences in their descriptions about the museum. The emotional experiences on this trip are descriptions that indicate their happiness, enjoyment, 
liking and willingness to experience the same experience again. They also expressed their gratitude to officials and trainers who provided opportunities to these experiences for them.

Another subcategory reached in the experiences of museum category of the research is attitude descriptions. Below are the texts of attitudes that students expressed at end of the experience they lived (Table 4).

Table 4. Reflection of Students' Experiences in ADNHM on Attitudes

\begin{tabular}{ll}
\hline Expressions of Students & Code No and Description \\
\hline S34:.. What I learned here, let's protect nature. & Code 26: Protecting nature \\
\hline S25: Let's not throw garbage around / Let's protect the & Code 26: Protecting nature, Code 27: \\
nature / Let's keep the environment clean / Let's plant & Not throwing garbage, Code 28: \\
trees / Let's warn the people who throw garbage. & Reforestation \\
\hline $\begin{array}{l}\text { S87: I have learned the characteristics of animals, plants } \\
\text { in nature, I want to teach }\end{array}$ & \\
\hline S106: I will follow what is told to me after that. & Code 30: Reflecting on her/his life \\
\hline S345: There may still be creatures that we do not know in & Code 31: Doing scientific research \\
the land. Maybe they are useful or harmful to us. We need & \\
to investigate in order to know. We may cope with fatal & \\
diseases, we search to learn. I think we can face a lot of \\
obstacles in life, to me, let's learn immediately
\end{tabular}

Primary school students made positive descriptions about the nature such as protecting the nature, not throwing away garbage, afforestation after their journeys in ADNHM. In addition, this trip has enabled them to develop attitudes about doing scientific research and sharing cognitive learning experiences.

\section{Discussion and Conclusion}

As a result of the research, they describe the expectations and estimates of primary school students about their experiences in the ADNHM as learning old things, animals, animals that are extinct today, and the history of nature. Because of the large number of historical, archaeological and ethnographical museums in Turkey, primary school students regard ADNHM as a place where historical artifacts and ancient animals are found. Another reason for their portrayal in this way may be the result of conceptual structure of ADNHM. When some students express their expectations, they describe as seeing the living and non-living components of nature and, as medium that provides recognizing nature closely.

When the experiences of the students in the natural history museum are examined, it is determined that these experiences are composed of three categories. These are experiences, emotional experiences and attitudes of primary school students about observation results. When we look at the descriptions of students' observation experiences, it has been determined that they can count the general characteristics and names of some living things, and can make simple classifications. In addition, the environment in natural history museum has been providing them experiences emotionally. Frozen animals, insect species, fossil specimens, rock collections, living forms, which they saw in museum, surprise students. Their interest in living things that they have never encountered before is increasing. In emotional terms, the students said they wanted to spend most of their time in this museum. They have defined this museum as a beautiful and fun educational environment that they can bring their loved ones and shared their gratitude. In addition, after the museum education, they developed positive attitude expressions about being more conscious against nature. The museum education program led to a change in attitudes of students. The students reviewed their behaviors and behaved impatiently while showing their willing behaviors. 
To sum up, Ali Demirsoy Natural History Museum is an environment, serving the development of the skills of observing and recognizing living and non-living forms, which increases the interest and attitudes of the students living in the eastern part of Turkey, beyond their expectations due to the physical and cultural conditions of the region. Dilli (2016), states that the educational activities that primary school students realized in the natural history museum have provided students with opportunities to understand themselves and others, to understand development of living organisms, to preserve and sustain cultural heritage, to make meaningful connections with past, present and future, and to develop value and awareness about the close and remote environment. Similarly, Anderson and Piscitelli (2002), when children are allowed to be free at their activities in the museum, this situation provides them thinking museum as a place where they are excited and happy, providing opportunities for learning, learning and acquiring different views. Memişoğlu ve Kamçı (2013), in their work on primary school students, they stated that the attitudes of students towards the museum were positive and it was a suitable environment for social studies lesson. As part of this lesson students want to visit the museums. Rapp (2005) highlightes that we must link the activities in the museums with the topics in the curriculum in the school and to organize the events in the school after the museum tour, provided cognitive and social benefits to the students. Similarly, Güler (2011) too, ponts out that a planned museum visit has affected the attitudes of primary school students towards the visual arts lesson positively. In the research, it can be said that student visits to natural history museums affected positively the attitudes towards nature and environment, which is the main source of science education. However, whether it is an archaeological or natural history museum, it would be a wrong idea to reduce any kind of museum to the field of education. Because, activities on science education can easily be done in archaeological, historical or ethnographic museums. The number of natural history museums in Turkey should be increased in order to increase the interest, attitude and motivation of student who are our future and education should not be limited with classroom environment. Teaching activities inside and outside of classroom environment should give our students the idea that a student can be life-long learner everywhere.

\section{References}

Adıgüzel, Ö. (2006). Okul dışında farklı bir öğrenme ortamı olarak çocuk müzeleri. Bilim Ĕ̆itim ve Toplum Dergisi, 4(14), 32-41. Akmehmet, T. K., \& Ödekan, A. (2006). Müze eğitiminin tarihsel gelişimi. İTÜ Sosyal Bilimler Dergisi, 3(1), 47-58.

Allen, S. (2004). Designs for learning: Studying science museum exhibits that do more than entertain. Science Education, 88(1), 17-33.

Anderson, D., \& Lucas, K. B. (1997). The effectiveness of orienting students to the physical features of a science museum prior to visitation. Research in Science Education, 27(4), 485-495.

Anderson, D., \& Piscitelli, B. (2002). Parental recollections of childhood museum visits. Parental recollections of childhood museum visits. Museum National, 10(4), 26-27.

Atagök, T. (1999). Çă̆daş müzeciliğin anlamı. İstanbul: Lami Sanat.

Canl1, K. (2016). Illkokul 4. sınıf görsel sanatlar dersinde sanal müze uygulamasına ilişkin öğretmen, öğrenci ve veli görüşleri. Yayınlanmamış Yüksek Lisans Tezi. Necmettin Erbakan Üniversitesi Eğitim Bilimleri Enstitüsü, Konya.

Çetin, Y. (2002). Çağdaş eğitimde müze eğitiminin rolü ve önemi. Atatürk Üniversitesi Güzel Sanatlar Enstitüsü Dergisi, 58(8), 5761.

Cox-Peterson, A. M., Marsh, D. D., Ksiel, J., \& Melber, L. M. (2003). Investigation of guided school tours, student learning, and science reform recommendations at a museum of natural history. Journal of Research in Science Teaching, 40(2), 200-218.

Creswell, J. W. (2007). Qualitative inquiry \& research design: Choosing among five approaches (2nd ed.). Thousand Oaks, CA: Sage Publications.

Demirsoy, A. (1996). Uygarlık yolunda önemli bir adım; Doğa tarihi müzeleri. Bilim ve Teknik Dergisi, 346, 64-69.

Dilli, R. (2014). Doğa tarihi müzelerinin eğitimdeki rolü. Dumlupınar Üniversitesi Sosyal Bilimler Dergisi, 40, 81-96.

Dilli, R. (2016). Conducting museum education activities with in the contex of developing a nature culture in primary school students: MTA natural history museum example. International Journal of Environment \& Science Education, 11(2), 75-84.

Egüz, Ş., \& Kesten, A. (2012). Sosyal bilgiler dersinde müze ile eğitimin öğretmen ve öğrenci görüşlerine göre değerlendirilmesi: Samsun ili örneği. İnönü Üniversitesi Eğitim Fakültesi Dergisi, 13(1), 81-103.

Falk, J. H., \& Dierking, L. D. (1997). School field trips: Assessing their long-term impact. Curator: The Museum Journal, 40, $211-$ 218.

Finson, K. D., \& Enochs, L. G. (1987). Student attitudes toward science-technology-society resulting from visitation to a sciencetechnology museum. Journal of Research in Science Teaching, 24(7), 593-609. 
Gilbert, J., \& Priest, M. (1997). Models and discourse: a primary school science class visit to a museum. Journal of Science Education, 81(6), 749-762.

Güleç, S., \& Alkış, S. (2003). Sosyal bilgiler öğretiminde müze gezilerinin iletişimsel boyutu. Uludă̆ Üniversitesi Eğitim Fakültesi Dergisi, 17(1), 63-78.

Güler, A. (2011). Planlı bir müze gezisinin ilköğretim öğrencilerinin tutumuna etkisi. İlköğretim Online, 10(1), 169-179

Hein, G. E. (1998). Learning in the museum. London: Routledge.

Hooper-Greenhill, E. (1999). Müze ve galeri eğitimi (Öre-Evren, M. ve Kapçı, E.G. Çev.). Ankara: Ankara Üniversitesi Yayınevi.

ICOM (International Council of Museum). Retriewed from http://icom.museum/the-vision/museum-definition/ .

İslamoğlu, Y. (2012). Kemaliye “Prof. Dr. Ali Demirsoy Doğa Tarihi Müzesi”. Popüler Bilim Dergisi, 36, 36-40.

Karadeniz, C., \& Okvuran, A. (2014). Müzede bir gece: Ankara üniversitesi öğrencileriyle çorum arkeoloji müzesi'n de müze eğitimi. Elementary Education Online, 13(3), 865- 879.

Kaya-Koçak, S. (2010). Illköğretim görsel sanatlar eğitimi dersindeki müze etkinliklerine yönelik, öğrenci, öğretmen ve müze yetkililerinin görüşleri. Yayınlanmamış Yüksek Lisans Tezi. Gazi Ünivesritesi Eğitim Bilimleri Enstitüsü, Ankara.

Kuruoğlu-Maccario, N. (2002). Müzelerin eğitim ortamı olarak kullanımı. Uludă̆ Üniversitesi Ĕ̆itim Fakültesi Dergisi, 15(1), 275 285.

Lichtman, M. (2010). Qualitative research in education: A user's guide (2nd ed.). Thousand Oaks, CA: Sage.

Martin, J. A., Durksen, T. L., Williamson, D., Kiss, J., \& Ginns, P. (2016). The role of a museum-based science education program in promoting content knowledge and science motivation. Journal of Research in Science Teaching, 53(9), 1364-1384.

Memişoğlu, H., \& Kamçı, S. (2013). Museum of social studies in education students attitudes and views. International Journal on New Trends in Education and Their Implications, 4(3), 121-138

Mercin, L. (2006). Resim dersini müze kaynaklı oluşturmacı öğrenme yaklaşımı etkinliklerine göre uygulamanın erişiye, kahıılı̆̆a ve tutuma etkisi. Yayımlanmamış Doktora Tezi. Gazi Üniversitesi Eğitim Bilimleri Enstitüsü, Ankara

Michie, M. (1998). Factors influencing secondary science teachers to organise and conduct field trips. Australian Science Teacher Journal, 44(4), 43-50.

Mortensen, F. M., \& Smart, K. (2007). Free-choice worksheets increase students' exposure to curriculum during museum visits. Journal of Research in Science Education, 44(9), 1389-1414.

National Research Council (NRC). (2009). Learning science in informal environments. Washington, DC: National Academies Press.

Osborne, J., \& Dillon, J. (2007). Research on learning in informal contexts: Advancing the field?. International Journal of Science Education, 29(12), 1441-1445

Rapp, W. (2005). Inquiry-based environments for the inclusion of students with exceptional learning needs. Remedial and Special Education, 26(5), 297-310.

Reiners, G. M. (2012). Understanding the differences between Husserl's (descriptive) and Heidegger's (interpretive) phenomenological research. Journal of Nursing \& Care, 1(119). Retriewed from https://www.omicsgroup.org/journals/understanding-the-differences-husserls-descriptive-and-heideggers-interpretivephenomenological-research-2167-1168.1000119.pdf .

Rennie, L., \& McClafferty, T. (1995). Using visits to interactive science and technology centers, museums, aquaria, and zoos to promote learning in science. Journal of Science Teacher Education, 6(4), 175-185.

Saban, A., \& Ersoy, A. (2016). Ĕ̆itimde nitel araştırma desenleri (1. Baskı). Ankara: Anı Yayıncılık

Şahan, M. (2005). Müze ve Eğitim Türk Eğitim Bilimleri Dergisi, 4(3), 487-501.

Şar, E., \& Sağkol, T. (2013). Eğitim fakültelerinde müze eğitimi dersi gerekliliği üzerine. Hasan Ali Yücel Eğitim Fakültesi Dergisi, 10(2), 83-90.

Selanik-Ay, T., \& Kurtdede-Fidan, N. (2014). Öğretmen adaylarının sosyal bilgiler dersinde müzelerden yararlanmaya ilişkin görüşleri. Elektronik Sosyal Bilimler Dergisi, 13(48), 69-89.

Shaby, N., Ben-Zvi Assaraf, O., \& Tishler, C.E. (2016). The goals of science museums in the eyes of museum pedagogical staff. Learning Environment Research, 19(3), 359-382. Doi: 10.1007/s10984-016-9211-z.

Stetson, R., \& Stroud, N. D. (2014). Pre-service teacher training at the museum school. Journal of Museum Education, 39(1), 67-77. Doi: 10.1080/10598650.2014.11510796.

Stocklmayer, S. M., Rennie, L. J., \& Gilbert, J. K. (2010). The roles of the formal and informal sectors in the provision of effective science education. Studies in Science Education, 46(1), 1-44. Doi: 10.1080/03057260903562284.

Tal, T., Bamberger, Y., \& Morag, O. (2005). Guided school visits to natural history museums in Israel: Teachers' roles. Science Education, 89(6), 920-935. Doi:10.1002/sce.20070.

To, C., Tenenbaum, H. R., \& Wormald, D. (2016). What do parents and children talk about at a Natural History Museum?. Curator the Museum Journal, 59(4), 323-459. Doi: 10.1111/cura.12174.

Tosun, O. S. (2009). Müze incelemelerinin ilköğretim okullarındaki görsel sanatlar eğitimine katkısı (Bolu ili örneği). Yayınlanmamış Yüksek Lisans Tezi, Dokuz Eylül Üniversitesi Eğitim Bilimleri Enstitüsü, İzmir.

Tran, U. L. (2007). Teaching science in museums: The pedagogy and goals of museum educators. Science Education, 91(2), 278297. Doi: $10.1002 /$ sce. 20193

Türkoğlu, A. (2009). Hayat boyu öğrenim kapsamında türkiye'de informal öğrenme üzerine ortak bir anlayı̧ geliştirme ve farkındalık oluşturma projesi konferansları bildiri kitabı. Ankara: Milli Eğitim Bakanlığı Talim ve Terbiye Kurulu Başkanlığı Yayınları. 